\title{
Haematological and in-vivo study of moringa oleifera seed
}

\begin{abstract}
The purpose of the study was to determine the hematological and nutritional evaluation of Moringa seed. Dietary Samples investigated consisted of Basal dietary, a nitrogen free diet 100\%(1) Control dietary (2) Basal80\%: Pressure cooked Moringa olifera seed $10 \%$ : soybean $10 \%(3)$ Basa180\%: Oven Roasted Moringa olifera seed10: soybean $10 \%$ (4) Basa180\%: Raw Moringa olifera seed10\%: Soybean10\%(5).

Fifty (50) albino rats were obtained from faculty of Health Science animal breeding centre, Obafemi Awolowo University, Ile-Ife, Nigeria. They were weighed and grouped into five groups of ten each and fed with (Figure 1) five dietary samples for 28days. A commercial product (Milk based) manufactured by Nestle Plc, was purchased from a local supermarket, Ile-Ife, Nigeria and was used as standard control. The growth rate, (non protein diet) for sample dietary 1 declined by $0.7 \%$. Protein samples dietary growth rate increased for samples dietary 2(39.1\%), 3(23.9\%), 4(23.8\%), and 5(17\%) respectively. Protein efficiency ratio (PER) Net protein ratio (NPR) Protein retention efficiency (PRE=NPRX16) measured for samples dietary 2, 3, 4, 5 were comparable to the control. The average nitrogen retained in various organs of experimental animals, such as liver, kidney and muscle of the diets 2, 3, 45 were favorably comparable to the control respectively. Hematological study of the blood serum analysis of the test rats showed significant $(\mathrm{p}<0.05)$ healthy conditions of the packed cell volume, hemoglobin, red blood cells, white blood cells and serum protein were comparable to the control rats. In conclusion Moringa oleifera dietary samples were good potential to be an alternative source to boost human and animal blood, protein, essential amino acids supplements. It is cheap, easily available, could improve human health, meet nutritional requirement for infants, reach at affordable price and available for the rural dweller populace.
\end{abstract}

Keywords: moringa olifera seed, hematological study, experimental animals, EDTA
Volume 4 Issue 6 - 2017

\author{
Samson Ishola Ibironke,' Morakinyo Meshach \\ IGE,' Adefisola Bola Adepeju² \\ 'Department of Food Science and Technology, Obafemi \\ Awolowo University, Nigeria \\ ${ }^{2}$ Department of Food Science and Technology, Joseph Ayo \\ Babalola University, Nigeria
}

Correspondence: Ibironke Sam Ishola, Department of Food Science and Technology, Obafemi Awolowo University, lle-lfe, Nigeria, 0220005, Te +23408034330259,

Email isolaibironke@yahoo.com

Received: July 07, 2017 | Published: August 23, 2017

\section{Introduction}

Moringa oleifera is a vegetable plant protein with bio-active multipurpose; it is originated from the sub-Himalayan areas of India, Pakistan, Bangladesh, Afghanistan and Tropics. The various parts of Moringa oleifera such as leaves, bark, flowers, fruit, seeds, and root are medicinal beneficiary Gunjul et al. ${ }^{1}$ Moringa oleifera is an important food source in some parts of the world because it can be grown cheaply and easily, and the leaves retain lots of vitamins and minerals when dried. Chemical analysis of Moringa oleifera seed consists of oil $\%$, protein $\%$, fiber $\%$, moisture $\%$ and ash $\%$ contents were $34.80 \%, 31.65 \%, 7.54 \%, 8.90 \%$ and $6.53 \%$ respectively, thus some people use it as a nutritional supplement or tonic. ${ }^{2}$ In India and Africa Moringa oleifera is used in feeding programs to fight malnutrition. The immature green pods (drumsticks) are prepared similarly nutritive values to green beans, while the seeds are removed from more mature pods and cooked like peas or roasted like nuts. ${ }^{3}$ The leaves are cooked and used like spinach, and they are also dried and powdered for use as a condiment. The seed cake remaining after oil extraction is used as a fertilizer and also to purify well water and to remove salt from seawater. ${ }^{3}$ Moringa oleifera is medically therapy for prevention of "tired blood" (anemia); arthritis and other joint pain (rheumatism); asthma; cancer; constipation; diabetes; diarrhea; epilepsy; stomach pain; stomach and intestinal ulcers; intestinal spasms; headache; heart problems; high blood pressure; kidney stones; fluid retention; thyroid disorders; and bacterial, fungal, viral, and parasitic infections. ${ }^{4}$
Other medical application of Moringa oleifera is to reduce swelling, increase sex drive prevent still birth pregnancy, boost the immune system, and increase breast milk production. Moringa oleifera is sometimes applied directly to the skin as a germ-killer or drying agent (astringent). It is also used tropically for treating several infection (abscesses), athlete's foot, dandruff, gum disease (gingivitis), snakebites, warts, and wounds. ${ }^{4}$ Socially oil from Moringa oleifera seeds is used in foods, perfume, and hair care products, and as a machine lubricant. ${ }^{4}$ Hence, the study aimed to determine the hematological analysis and the nutritional evaluation of Moringa oleifera seed diets Figures 2 \& Figure 3 from locally available, easily accessible plant protein such as Moringa oleifera seed soy bean and maize and (carbohydrate).

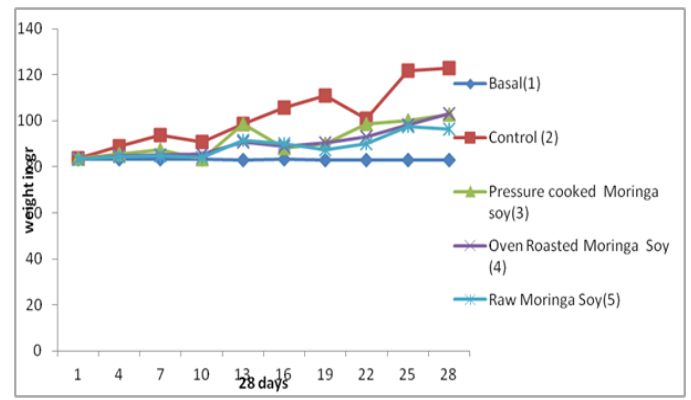

Figure I Shows the Growth response of animal fed with Moringa olifera dietary samples for 28days. 


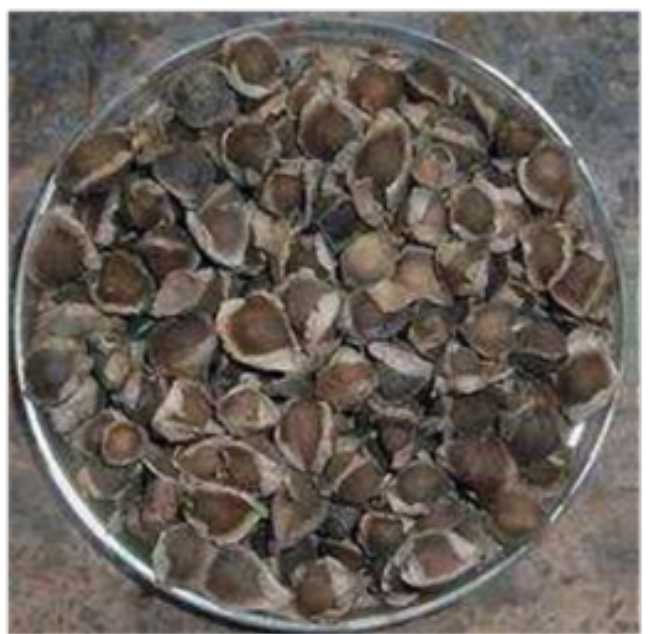

Figure 2 Moringa oleifera seeds with seed coating.

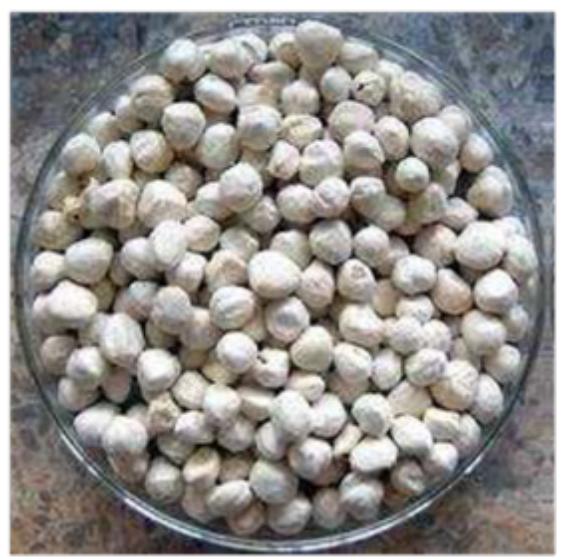

Figure 3 Moringa oleifera seeds without seed coating.

\section{Materials and methods}

Maize, soybean and a commercial product (Milk based) manufactured by Nestle plc was purchased from a local supermarket, Ile-Ife, Nigeria.

\section{Seed collection and processing}

Mature unshelled Moringa oleifera seed was collected for Obafemi Awolowo University Agriculture farm, Ile-Ife. The maize was soaked for one day, wet milled, made into dough and allowed to ferment for 48 hours, after which it was dried and milled into fine flour. Soy bean was also made into flour by first soaking for $48 \mathrm{hr}$, blanched at $100^{\circ} \mathrm{C}$, dehulled, oven dried at $80^{\circ} \mathrm{C}$, and milled into fine flour. Sample dietary was prepared Moringa oleifera seed was cleaned, was at cooked at $100^{\circ} \mathrm{C}$ dried and milled into fine flour, Pressure cooked Moringa seed10\%: soybean10\%(3) Moringa oleifera seed was cleaned sorted, oven dried at $80^{\circ} \mathrm{C}$, milled into fine flour Basal $80 \%$ : Oven Roasted Moringa oleifera seed10: soybean10\%(4), Moringa oleifera seed was sorted, cleaned, sun dried, milled into fine flour, Raw Moringa oleifera seed $10 \%$ : Soybean 10\%(5).The flours were packed into airtight polyethylene bags and stored in the freezer. ${ }^{5-7}$

\section{Biological Assay}

FIfty (50) weaning albino rats were obtained from College of Heath Science animal breeding centre, Obafemi Awolowo University, Ile-Ife, Nigeria. The albino rats were weighed and randomly allocated to metabolic cages. The weights and ages ranged from $83 \mathrm{~g}-83.74 \mathrm{~g}$ and 4 to 6 old weeks respectively. The albino rats were accommodated in metabolic cages fixed with a feeding plate and a small plastic bottle to supply food and water ad libitum. The animals were acclimatized to the new environment by feeding them for seven days on pellets specially prepared for animals. The animals were then re-weighed and grouped into five of ten per group in such a way that the weights were similar. For example groups, 1, 2, 3, 4 and 5 had almost similar weights at the beginning of the $83.70,83.7483 .45,83$ and 83.20 respectively. Groups (1-5) were placed on experimental diets for 28days. They were given a noted weighed quantity of each experimental diet, in a feeding dish and water was supplied ad libitum via a plastic bottle attached to the cage. Daily consumption of samples was carefully recorded and the weights were noted. Weight gain/loss of the experimental animals was taken every three days. Prior to the end of the experiment, which was twenty-eight days, the experimental animals were sacrificed. The organs collected from the animal including spleen, heart lungs kidney liver and small intestine were fixed immediately in $10 \%$ formyl saline for nitrogen determination..$^{8-12}$

\section{Automated blood count}

\section{Procedures}

Blood Count was performed in the Department of Hematology and Immunology, Faculty of Basic Medical Sciences, Obafemi Awolowo University, Ile-Ife using an Abbott Cell-Dyn 1700 automatic analyzer. The blood sample was collected through cardiac puncture, drawing the blood into a test tube containing an anticoagulant (EDTA) to stop it from clotting. The sample is then transported to the laboratory for immediate processing by an automated counter. The blood was well mixed (though not shaken) and placed on a rack in the analyzer. This instrument has flow cells, photometers and apertures that analyze different elements in the blood. The cell counting component counts the numbers and types of different cells within the blood. The results are printed out. This blood counting machine aspirates a very small amount of the specimen through narrow tubing followed by an aperture and a laser flow cell. Laser eye sensors count the number of cells passing through the aperture, and can identify them; this is flow cytometry. The two main sensors used are light detectors and electrical impedance. The instrument measures the type of blood cell by analyzing data about the size and aspects of light as they pass through the cells (called front and side scatter). Other instruments measure different characteristics of the cells to categorize them. Because an automated cell counter samples and counts so many cells like White cells, Red cells, Hemoglobin, Hematocrit, MCV, $\mathrm{MCH}$, MCHC, RDW, Platelets etc., the results are very precise AACC..$^{13}$

\section{Ethical consideration}

This study was approved by the Ethical Review Committee of the Obafemi Awolowo University, Osun State, Ile-Ife, Nigeria.

\section{Results and discuss}

Table 1 reflects the chemical composition of raw materials of 
the dietary samples in percentage include protein $\%$, moisture $\%$, fat $\%$, ash $\%$, fibre $\%, \mathrm{CHO} \%$ and energy $/ \mathrm{kcal} \%$, It was found to be nutritional adequate to formulate dietary and meet daily nutritional needs for infants and adults. The data are mean $\pm \mathrm{SD}$ values of three determinations with different superscript in a column are significantly different $(\mathrm{P}<0.05)$. Foot note: Basal dietary, a nitrogen free diet 100\%(1) Control dietary(2) Basal80\%: Pressure cooked Moringa olifera seed10\%: soybean10\%:(3) Basal80\%: Oven Roasted Moringa olifera seed10\%: soybean10\%(4) Basa180\%: Raw Moringa olifera seed $10 \%$ :Soybean $10 \%(5)$.

Table 2 showed the highlights of haematological study of Moringa oleifera samples dietary include $\mathrm{WBC} 10^{-3 / \mathrm{UL}}, \mathrm{LYM} \%$, MON\%,

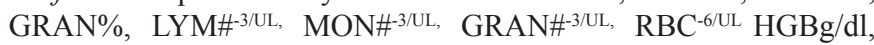
HCT\%, MCVfL, MCHpg, MCHC g/dl, RDW-SDfL, RDW-CV\%, PLT10-3/UL, MPVfL, PDW\%, PCT\% and P.LCR\%. Hematological study of the blood serum analysis of the experiment rats showed significant $(\mathrm{p}<0.05)$ healthy conditions of the packed cell volume, hemoglobin, red blood cells, white blood cells and serum protein were comparable to the control sample dietary experimental rats. This is in agreement with earlier report that Moringa oleifera could boost blood and hence an alternative food for anemia patients. ${ }^{14,15}$

The data are mean $\pm \mathrm{SD}$ values of three determinations with different superscript in a column are significantly different $(\mathrm{P}<0.05)$. Foot note: Basal dietary, a nitrogen free diet $100 \%(1)$ Control dietary(2) Basa180\%: Pressure cooked Moringa oleifera seed10\%: soybean $10 \%$ (3) Basal $80 \%$ : Oven Roasted Moringa oleifera seed10\%: soybean $10 \%$ (4) Basal80\%: Raw Moringa seed10\%:Soybean10\%(5). Table 3 highlights the chemical analysis of the five dietary samples which include protein $\%$, moisture $\%$, fat $\%$, ash $\%$, fibre $\%, \mathrm{CHO} \%$ and energy $/$ $\mathrm{Kcal} \%$. They were ranged from 10.22 to $10.30 \%, 4.25$ to $4.34 \%, 2.68$ to $3.80 \%, 2.30$ to $2.64 \%, 0.68$ to $0.88 \%$, and 78.91 to $88.85 \%$ and 382 to $389 \mathrm{Kcal} \%$ respectively. Samples dietary protein were formulated and regulated at $10 \%$ to enable calculate biological values. Levels of moisture $\%$ and fat $\%$ were less than $10 \%$ this values give an advantage to the samples dietary for example moisture $\%$ higher than $10 \%$ favour food spoilage and microorganism multiplication. Fat content below $10 \%$ could discourage rancidity and increase shelf life, higher $\mathrm{CHO}$ may result in higher energy supply to the body. Corroborate other studies. ${ }^{6,8,12,16,17}$

The data are mean \pm SD values of three determinations with different superscript in a column are significantly different $(\mathrm{P}<0.05)$. Foot note: Basal dietary, a nitrogen free diet100\% (1) Control dietary (2) Basal $80 \%$ : Pressure cooked Moringa olifera

Table I Proximate Composition of raw materials procured for dietary samples \% seed10\%: soybean10\%:(3) Basal80\%: Oven Roasted Moringa olifera seed10\%: soybean10\%(4) Basal80\%: Raw Moringa olifera seed10\%:Soybean $10 \%(5)$. Table 4 depicts the weight of various tissues of experimental animals in gram such as Liver (g), Muscle $(\mathrm{g})$, Kidney $(\mathrm{g})$, Heart $(\mathrm{g})$ and Spleen $(\mathrm{g})$. They were ranged from 3.54 to $4.54,0.46$ to $0.78,0.62$ to $0.90,0.32$ to 0.52 and 0.46 to 0.62 respectively. Samples dietary 2-5 were higher compared with sample dietary 1 because sample dietary 1 lack adequate nutrient to promote inner tissues growth. ${ }^{1,6,11,17}$

The data are mean \pm SD values of three determinations with different superscript in a column are significantly different $(\mathrm{P}<0.05)$. Foot note: Basal dietary, a nitrogen free diet $100 \%$ (1) Control dietary (2) Basal $80 \%$ : Pressure cooked Moringa olifera seed10\%: soybean $10 \%$ : (3) Basa180\%: Oven Roasted Moringa olifera seed10\%: soybean $10 \%$ (4) Basa180\%: Raw Moringa olifera seed10\%:Soybean10\% (5). Table 5 shows the Bioassay of experimental animals include biological value (BV \%), True digestibility (TD \%), Food efficiency ratio (FER), and Protein retention efficiency (PRE) Protein efficiency ratio (PER), net protein retention (NPR), net protein utilization (NPU) values They were 95.66 to $98.68,72.45$ to $80.55,3.0$ to $3.7,0.28$ to $0.37,2.9$ to 3.6 and 46.4 to 57.6 comparable to control samples and similar to biological value of an egg, the combination of two proteins in the formulation of sample dietary had reported previously to complement each other to form a complete amino acid profile but diet 1 lack biological value being a single plant protein, nitrogen free diet contain sulphur amino acid such as methionine but limited in lysine and tryptophan respectively. ${ }^{6,9,17}$

The data are mean \pm SD values of three determinations with different superscript in a column are significantly different $(\mathrm{P}<0.05)$. Foot note: Basal dietary, a nitrogen free diet100\% (1) Control dietary (2) Basal $80 \%$ : Pressure cooked Moringa olifera seed10\%: soybean10\%:(3) Basal80\%: Oven Roasted Moringa olifera seed10\%: soybean10\% (4) Basal80\%: Raw Moringa olifera seed $10 \%$ :Soybean $10 \%(5)$. Table 6 shows the total nitrogen content in tissue of experimental animal $\mathrm{mg} / 100 \mathrm{~g}$, the nitrogen content which includes Liver $(\mathrm{mg} / 100 \mathrm{~g})$, Muscle $(\mathrm{mg} / 100 \mathrm{~g})$ and Kidney $(\mathrm{mg} / 100 \mathrm{~g})$. They were ranged from 35.37 to $50.27,36.03$ to 50.53 , 35.03 and 50.20 respectively. The tissue store enough nitrogen that could promote growth and carry out other daily activities, however sample dietary 1 had lower nitrogen compared to group 2 to 5 , this might be because group 1 lack quality protein, single plant protein can not complete amino acid profile this is in agreement with other findings. ${ }^{6,8,17}$

\begin{tabular}{lccccccc}
\hline Sample code & Protein\% & Moisture\% & Fat\% & Ash\% & Fibre\% & CHO\% & Energy/kcal\% \\
\hline Moringa oleifera seed & $31.62 \pm 02$ & $2.56 \pm 01$ & $34.80 \pm 03$ & $6.53 \pm 03$ & $1.54 \pm 01$ & $22.95 \pm 01$ & $531 \pm 01$ \\
& & & & & & & \\
Maize & $9.88 \pm 03$ & $2.67 \pm 04$ & $0.45 \pm 01$ & $2.88 \pm 02$ & $1.68 \pm 02$ & $82.44 \pm 03$ & $373 \pm 03$ \\
& & & & & & & \\
Soy Bean & $38.66 \pm 01$ & $2.58 \pm 01$ & $20.56 \pm 02$ & $2.45 \pm 01$ & $1.88 \pm 01$ & $33.87 \pm 02$ & $681 \pm 01$ \\
\hline
\end{tabular}


Table 2 Haematological study of moringa oleifera seed

\begin{tabular}{|c|c|c|c|c|c|c|c|}
\hline Parameter & 1 & 2 & 3 & 4 & 5 & Limits & Alerts \\
\hline $\mathrm{WBC} 10^{-3 / \mathrm{UL}}$ & 6.3 & 6.6 & 6.8 & 11.6 & 9 & $2.5-10.5$ & $\mathrm{~m}$ \\
\hline LYM\% & 73.9 & 89.2 & 84.1 & 73.9 & 62.2 & $20-40$ & $\mathrm{H}$ \\
\hline MON\% & 68 & 6.6 & 9.9 & 12 & 13.6 & 15-Jan & $\mathrm{m}$ \\
\hline GRAN\% & 14.1 & 4.3 & 6 & 14.1 & 24.3 & $50-70$ & $\mathrm{~L}$ \\
\hline $\mathrm{LYM}^{-3 / \mathrm{UL}}$ & 8.6 & 6.6 & 6.6 & 8.6 & 6.6 & $0.6-4.1$ & $\mathrm{H}$ \\
\hline $\mathrm{MON}^{-3 / \mathrm{UL}}$ & 1.4 & 0.4 & 0.7 & 1.4 & 1.2 & $0.1-1.8$ & $\mathrm{~m}$ \\
\hline GRAN $^{\#-3 / U L}$ & 1.6 & 0.3 & 0.3 & 1.6 & 2.2 & $2.0-7.8$ & $\mathrm{~L}$ \\
\hline $\mathrm{RBC}^{-6 / \mathrm{UL}}$ & 6.76 & 6.62 & 8.5 & 6.76 & 6.64 & $3.50-6.50$ & $\mathrm{~m}$ \\
\hline $\mathrm{HGBg} / \mathrm{dl}$ & 12 & 12.7 & 16.4 & 12 & 11.3 & 16-Nov & $\mathrm{m}$ \\
\hline НСТ\% & 34.2 & 39.1 & 48 & 34.2 & 31.8 & $36-48$ & $\mathrm{~m}$ \\
\hline MCVfL & 60.6 & 69.1 & 56.5 & 60.6 & 48 & $80-99$ & $\mathrm{~L}$ \\
\hline MCHpg & 17.7 & 19.1 & 19.2 & 17.7 & 17 & $26-32$ & $\mathrm{~L}$ \\
\hline MCHC g/dl & 32 & 32.4 & 34.1 & 36 & 35.5 & $32-36$ & $\mathrm{~m}$ \\
\hline $\mathrm{RDW}^{\text {-SDfL }}$ & 24.1 & 35.3 & 29.7 & 24.1 & 24.1 & $37-54$ & $\mathrm{~L}$ \\
\hline $\mathrm{RDW}^{-\mathrm{CV} \%}$ & 13.6 & 17.4 & 16.3 & 13.6 & 14.2 & $11.5-14.5$ & $\mathrm{H}$ \\
\hline PLT10 $0^{-3 / \mathrm{UL}}$ & 440 & 503 & 391 & 511 & 449 & $90-400$ & $\mathrm{~m}$ \\
\hline MPVfL & 6 & 6.7 & 7 & 9.2 & 10.7 & $7.4-10.4$ & $\mathrm{~L}$ \\
\hline PDW\% & 7 & 7.9 & 7.9 & 10 & 8.4 & 17-Oct & $\mathrm{L}$ \\
\hline РCT\% & 0.47 & 0.33 & 0.27 & 0.1 & 0.48 & $0.10-0.28$ & $\mathrm{~m}$ \\
\hline P.LCR\% & 13.3 & 18.3 & 18.3 & 13 & 23.7 & $13-43$ & $\mathrm{~L}$ \\
\hline
\end{tabular}

Table 3 Chemical analysis of five dietary samples

\begin{tabular}{|c|c|c|c|c|c|c|c|}
\hline Dietary samples & Protein $\%$ & Moisture\% & Fat $\%$ & Ash\% & Fibre\% & СНО\% & Energy Kcal\% \\
\hline 1 & - & $4.25 \pm 04$ & $3.80 \pm 01$ & $2.30 \pm 01$ & $0.80 \pm 04$ & $88.85 \pm 02$ & $389 \pm 04$ \\
\hline 2 & $10.25 \pm 01$ & $4.33 \pm 01$ & $3.20 \pm 02$ & $2.34 \pm 03$ & $0.86 \pm 01$ & $79.07 \pm 01$ & $385 \pm 02$ \\
\hline 3 & $10.22 \pm 02$ & $4.34 \pm 03$ & $2.78 \pm 01$ & $2.32 \pm 04$ & $0.76 \pm 04$ & $79.60 \pm 03$ & $384 \pm 01$ \\
\hline 4 & $10.30 \pm 03$ & $4.26 \pm 01$ & $3.30 \pm 03$ & $2.35 \pm 01$ & $0.88 \pm 01$ & $78.91 \pm 02$ & $386 \pm 03$ \\
\hline 5 & $10.24 \pm 01$ & $4.34 \pm 02$ & $2.68 \pm 03$ & $2.64 \pm 03$ & $0.68 \pm 02$ & $79.46 \pm 01$ & $382 \pm 04$ \\
\hline
\end{tabular}

Table 4 Weight of various tissues of experimental animals in gram

\begin{tabular}{llllll}
\hline Dietary samples & Liver(g) & Muscle(g) & Kidney(g) & Heart(g) & Spleen $(g)$ \\
\hline 1 & $3.44 \pm 01$ & $0.44 \pm 01$ & $0.62 \pm 03$ & $0.30 \pm 01$ & $0.36 \pm 02$ \\
2 & $4.54 \pm 03$ & $0.58 \pm 03$ & $0.86 \pm 01$ & $0.32 \pm 01$ & $0.62 \pm 03$ \\
3 & $3.98 \pm 02$ & $0.58 \pm 04$ & $0.90 \pm 02$ & $0.52 \pm 02$ & $0.46 \pm 01$ \\
4 & $3.50 \pm 01$ & $0.46 \pm 01$ & $0.84 \pm 01$ & $0.38 \pm 03$ & $0.46 \pm 04$ \\
5 & $3.54 \pm 04$ & $0.66 \pm 02$ & $0.82 \pm 02$ & $0.44 \pm 03$ & $0.54 \pm 01$ \\
\hline
\end{tabular}


Table 5 Bioassay of experimental animals

\begin{tabular}{lllllll}
\hline Dietary samples & BV\% & TD\% & PER & FER & NPR & PRE \\
\hline 1 & - & - & - & - & - & - \\
2 & $98.68 \pm 03$ & $80.55 \pm 00$ & $3.7 \pm 03$ & $0.37 \pm 03$ & $3.6 \pm 03$ & $57.6 \pm 03$ \\
3 & $96.65 \pm 01$ & $76.56 \pm 01$ & $3.5 \pm 02$ & $0.34 \pm 01$ & $3.5 \pm 01$ & $56.0 \pm 02$ \\
4 & $95.66 \pm 02$ & $74.55 \pm 03$ & $3.4 \pm 03$ & $0.39 \pm 03$ & $3.2 \pm 02$ & $51.2 \pm 01$ \\
5 & $95.80 \pm 03$ & $72.45 \pm 02$ & $3.0 \pm 01$ & $0.28 \pm 02$ & $2.9 \pm 03$ & $46.4 \pm 01$ \\
\hline
\end{tabular}

Table 6 The total nitrogen content in tissue of experimental animal mg/l00g

\begin{tabular}{llll}
\hline Dietary samples & Liver(mg/100g) & Muscle(mg/100g) & Kidney(mg/100g) \\
\hline 1 & $35.37 \pm 01$ & $36.03 \pm 03$ & $35.03 \pm 02$ \\
2 & $50.27 \pm 02$ & $50.53 \pm 01$ & $50.00 \pm 01$ \\
3 & $50.25 \pm 03$ & $50 . .50 \pm 02$ & $50.20 \pm 04$ \\
4 & $50.26 \pm 03$ & $50 . .53 \pm 01$ & $50.00 \pm 02$ \\
5 & $48.27 \pm 01$ & $43 . .53 \pm 02$ & $48.00 \pm 03$ \\
\hline
\end{tabular}

\section{Conclusion}

In conclusion Moringa oleifera dietary has prove to be biochemical active, alternative plant protein source to boost human and animal blood, protein, and essential amino acids supplements. It is highly digestible, could promote growth, improve health, meet nutritional requirement for infants and adult, could be reached at affordable price and available for the rural dweller populace could be applied for health therapy and human consumption, healthy conditions of the packed cell volume, hemoglobin, red blood cells, white blood cells and serum protein were comparable to the control sample dietary experimental rats.

\section{Acknowledgements}

The authors are grateful to the students and staff of the Department of Food Science and Technology, Obafemi Awolowo University, IleIfe, Nigeria.

\section{Conflicts of interest}

The author declares no conflict of interest.

\section{References}

1. Gunjul Mahendral A, Shah Abhishek S, Wakade Alok S, et al. Protective effect of aqueous extract of Moringa oleifera Lam. stem bark on serum lipids, marker enzymes and heart antioxidant parameters in insoproterenolinduced cardiotoxicity in Wista rats. Indian Journal of Natural Products and Resourses. 2010;1(4):485-492.

2. Aberra Melesse, Kefyalew Berihun. Chemical and mineral compositions of pods of moringa stenopetala and moringa oleifera cultivated in the lowland of gamogofa zone. J Environ Occup Sci. 2013;2(1):33-38.

3. Mangale SM, Chonde SG, Jadhav AS, et al. Study of moringa oleifera (Drumstick) seed as natural absorbent and antimicrobial agent for river water treatment. J Nat Prod Plant Resour. 2012;2(1):89-100.

4. Farooq anwar, Umer rashid. Physico-chemical characteristics of Moringa oleifera seeds and seed oil from a wild provenance of pakistan. PakJ Bot. 2007;39(5):1443-1453.
5. Seena Sahadevan, Sridhar R kandikere, Ramesh R sarafa. Nutritional and protein evaluation of thermally treated seeds Canavalia maritima in the rat. Nutiritional Reseach. 2005;25:587-596.

6. Ibironke SI, Akinola EA, Adepeju AB. Comparative study of condiment vegetable basil leaf (Ocimum gratissimum) and bitter leaf (Vernonia Amygdalina). American Journal of Food and Nutrition. 2017;5(3):95-98.

7. Ibironke Samson Ishola, Adeniyi Mojisola Aderonke, Joseph Bandele Fashakin. Nutritional evaluation of complementary food formulated from fermented maize, pigeon pea and soybeans. Nutrition And Food Science. 2014;44(5):464-470.

8. Ibironke Samson Ishola, Joseph Bandele Fashakin, Badmus OA Nutritional evaluation of complementary food developed from plant and animal protein sources. Nutrition \& Food Science. 2012;42(2):111-120.

9. Ibironke, S Ishola, Joseph B Fashakin, et al. Nutritional quality of animal polypeptide (Crayfish) formulated into complementary foods. American Journal of Food and Nutrition. 2014;2(3):39-42.

10. Ibironke, Samson Ishola, Joseph Bandele Fashakin, et al. Formulation of complementary foods developed from plants polypeptide (Parkia Biglobosa), Soy bean and maize. American Journal of Nutrition and Food Science. 2014;1(4):72-77.

11. Ibironke Samson Ishola. Formulation of infant weaning foods from vegetable proteins and cereal. American Journal of Food Technology. 2014;9(2):104-110.

12. Ibironke Samson Ishola. Physico-chemical parameters and water quality of opa water irrigation, Ile-ife, South-west, Nigeria. American Journal of Food Technology. 2014;9(2):111-116.

13. AACC. American Association for Clinical Chemistry. Washington, USA: DC 20001; 2017.

14. Yahaya T, Okpuzor J, Ajayi T. The prophylactic efficacy of roselle $[H$. Sabdariffa], moringa [moringa oleifera], ginger [Z. Officinale] and ugwu [T. Occidentalis] on the hematology and serum protein of albino rats [rattus norvegicus] exposed to cement dust. Reseacrh of medicinal plant. 2012;6(2):189-196.

15. Ibironke SI, Ige MM, Bejide RA. Histopathological and In-Vivo study of moringa oleifera seed. Annals Food Science and Technology. 2016;17(1):102-108. 
16. AOAC. Official Methods of Analysis of the Association of Official. Analytical Chemists, (17th ed. USA: Washington Dc; 2000.
17. Oloyede FM, Oloyede FA, Obuotor EM, et al. Antioxidant activities and food value of five underutilized green leave vegetables in South Western Nigeria. The Nigerian Journal of Nutritional Science. 2011;32:13-18. 